\title{
Potential of Moringa Oleifera Seed as a Natural Adsorbent for Wastewater Treatment
}

\author{
Manoj Pandurang Wagh ${ }^{*}$, Yashwant Aher and Anit Mandalik \\ Department of Civil Engineering, Dr. Vithalrao Vikhe Patil College of Engineering Ahmednagar, \\ Maharashtra, India
}

('Corresponding author's e-mail: profmpwagh@gmail.com)

Received: 8 September 2020, Revised: 5 March 2021, Accepted: 25 March 2021

\begin{abstract}
The present study deals with the appropriateness of the coagulation process using natural coagulant Moringa oleifera seed. Natural coagulants are useful for the treatment of wastewater because of its sustainability, cost-effectiveness, non-toxicity and lesser quantity of sludge formation. M. oleifera seed having a chemical composition of polypeptides having 6 amino acids like arginine acid, methionine acid, glutamic acid, phenylalanine, threonine, and histidine. $M$. oleifera is also known as a cationic polyelectrolyte and having molecular weight 6,000 to16,000 Dalton. The main objective of research work is the application of the $M$. oleifera seed as a natural adsorbent to treat synthetic dairy wastewater. The effects of $\mathrm{pH}$, agitation time, the dose of sorbent and efficacy of $M$. oleifera seeds kernel for turbidity removal was assessed. $M$. oleifera seed eliminates turbidity $95 \%$ and colour $94 \%$ using 0.22 gm pod powder, and $0.2 \mathrm{~L}$ of $1.0 \mathrm{~g} / \mathrm{L}$ synthetic dairy wastewater. Naturally dried $M$. oleifera seeds remove turbidity $95 \%$, sundried seeds remove turbidity $52 \%$ and oven-dried seeds $45 \%$. As naturally dried $M$. oleifera pod having more surface area for adsorption and inter-particulate bridging which extract the extra active ingredients. $\mathrm{pH}$ range between 5 and 8 is more suitable to degrade the turbidity and colour. It is concluded that in the presence of an aqueous soluble cationic coagulant protein has great potential to remove the turbidity and colour of wastewater.
\end{abstract}

Keywords: Moringa oleifera (M. oleifera), Bio-sorption, Chemical oxygen demand (COD), Turbidity, Coagulation

\section{Introduction}

M. oleifera is a tropical plant from the family of Moringaceae, that is cultivated rapidly in the arid zone and has an average height of $10-12 \mathrm{~m}$, commonly known as moringa, drumstick [1]. Dry seeds of $M$. oleifera are water-soluble and is used as a natural coagulant to treat effluent and turbid water on a large scale [2]. M. oleifera is a medium size multipurpose tree found in northwest India and native to various parts of Asia, South America and Africa [3]. Pods of M. oleifera are non-hazardous and can be utilized as an economical and effective sorbent for the elimination of organics [4]. Application of alum and lime is a conventional coagulant used for water treatment worldwide. If other chemical such as sodium hydroxide is implemented to treat the water the total cost increases annually which is quite difficult for developing countries to cope with $[2,5]$. The natural coagulants are extremely efficient in degradation of Physico-chemical properties of wastewater like chemical oxygen demand, biochemical oxygen demand, turbidity, colour, etc $[1,6]$. Planted-based coagulants such as Moringa oleifera, Cactus and Strychnos potatoru are effective coagulants. Table 1 illustrate that the efficiency of M. Oleifera seeds to treat turbidity of various wastewater. 
Table 1 Efficiency of M. Oleifera seeds to treat turbidity [30].

\begin{tabular}{cccc}
\hline Wastewater & $\begin{array}{c}\text { Initial turbidity in } \\
\text { (NTU) }\end{array}$ & Coagulant dosage & $\begin{array}{c}\text { Turbidity } \\
\text { removed (\%) }\end{array}$ \\
\hline Irrigation & $<50-50$ & $\begin{array}{c}\text { MOC-DW } 3-5 \% \mathrm{w} / \mathrm{v} \\
20-120 \mathrm{~mL} / \mathrm{L}\end{array}$ & $94-99.5$ \\
\hline Dairy industry & $85-145$ & $0.75-1.24 \mathrm{~g} / \mathrm{L}$ & 98 \\
\hline Synthetic & $10-1,000$ & MOC-SC $5-50 \mathrm{mg} / \mathrm{L}$ & $50-99.4$ \\
\hline Color water & $47-48$ & MOC-DW $100-500 \mathrm{mg} / \mathrm{L}$ & 92 \\
\hline Synthetic & 200 & MOC-SC $20-30 \mathrm{mg} / \mathrm{L}$ & $93-96$ \\
\hline Synthetic & 105 & $500 \mathrm{mg} / \mathrm{L}$ & 98 \\
\hline Raw wastewater & $184-226$ & MOC-DW 4 mL/L & 80 \\
\hline Synthetic & 25 & MOC-SC $20-200 \mathrm{mg} / \mathrm{L}$ & 57.9 \\
\hline Synthetic & 30 & MOC-SC $50-1,000 \mathrm{mg} / \mathrm{L}$ & 78.1 \\
\hline Tanning wastewater & 121.9 & $10-50 \mathrm{mg} / \mathrm{L}$ & $71-76$ \\
\hline Dye industry & $64.2-102$ & $0-50 \mathrm{mg} / \mathrm{L}$ & $45-95$ \\
\hline Food industry & 266.9 & $0-60 \mathrm{mg} / \mathrm{L}$ & $40-90$ \\
\hline Distillery industry & $499-510$ & $20-80 \mathrm{~mL} / \mathrm{L}$ & 99 \\
\hline
\end{tabular}

The application of these natural coagulants reduces sludge volume by increasing the floc size, as they are having properties like long-chain polymer, high cationic charge density, high biodegradability, non-toxic, and eco-friendly [2,7]. To achieve this sustainable development, it is necessary to put into service the plant-based natural coagulant [3,8]. It is an eco-friendly and cheaper method for purification of industrial wastewater as compared to common coagulants like alum [2-4,9]. Table 2 shows the comparison between chemical (common) coagulant and natural coagulants.

Table 2 Comparison between chemical (common coagulant) and natural coagulants.

\begin{tabular}{ccc}
\hline Parameters & Chemical coagulant & Natural coagulant \\
\hline Quantity & More coagulant dose is required & Less amount dose is required \\
\hline Efficiency & $\begin{array}{c}\text { More dose of coagulant leads to } \\
\text { more dissolved solids }\end{array}$ & $\begin{array}{c}\text { Natural coagulants are not leading to } \\
\text { formation of dissolved solids }\end{array}$ \\
\hline Toxicity & Extremely toxic & Non-toxic \\
\hline Sludge & Sludge generated on a large scale & Small quantity sludge generated \\
\hline Removal of heavy metals & Heavy metals cannot be & Heavy metals can be settled with \\
eliminated & coagulants \\
\hline pH & Significant changes in the pH & No significant variations in the pH \\
\hline Financial scheme & Costly & Economical, easily available \\
\hline
\end{tabular}

To eliminate colloidal particles from wastewater numerous conventional methods were used, such as coagulation, flocculation, flotation, solvent extraction, adsorption, ion exchange, membrane filtration, precipitation, and biological methods [10]. The coagulation/flocculation process draws attention for the elimination of dissolved, colloids, suspended and organic matter present in industrial effluent [4,6,10,11]. Extraction of $M$. oleifera was more efficient than $\mathrm{FeCl}_{3}$ to degrade the Clostridium perfringens spores extensively [7,12]. Moringa oleifera seed and powder are competent to treat textile wastewater and also can be effectively used in purification of groundwater $[8,13]$. M. oleifera coagulant protein act as a coagulant to minimize the alkalinity and hardness of turbid water [9,14]. By the application of chemical coagulant, sludge is generated on a large scale and disposal of this toxic Sludge is a major problem in current circumstances. Table 3 shows the basic advantages and limitations of chemical coagulants. 
Table 3 Synthetic/inorganic coagulants advantages and disadvantages.

\begin{tabular}{|c|c|c|c|}
\hline Sr. No & Coagulants & Advantages & Disadvantages \\
\hline 1 & $\begin{array}{l}\text { Aluminium sulphate } \\
\text { (Alum) } \\
\mathrm{Al}_{2}(\mathrm{SO} 4)_{3} \cdot 18 \mathrm{H}_{2} \mathrm{O}\end{array}$ & $\begin{array}{l}\text { Commonly practiced on a bulky scale, } \\
\text { easy to operate and handle. Generates a } \\
\text { lesser quantity of sludge than lime. } \\
\text { Competent for pH } 6.5 \text { and } 7.5\end{array}$ & $\begin{array}{l}\text { Competent for limited pH } \\
\text { range. Dissolved solids } \\
\text { salts were enhanced in } \\
\text { water. }\end{array}$ \\
\hline 2 & $\begin{array}{l}\text { Sodium Aluminate } \\
\qquad \mathrm{Na}_{2} \mathrm{Al}_{2} \mathrm{O}_{4}\end{array}$ & $\begin{array}{l}\text { It requires normally small dosage. More } \\
\text { effective to eliminate the hardness of } \\
\text { water. }\end{array}$ & $\begin{array}{l}\text { Costly, ineffective for soft } \\
\text { water. }\end{array}$ \\
\hline 3 & $\begin{array}{c}\text { Polyaluminium } \\
\text { Chloride } \\
\text { (PAC) } \\
\mathrm{Al}_{13}(\mathrm{OH})_{20}(\mathrm{SO})_{4} \cdot \mathrm{Cl}_{15}\end{array}$ & $\begin{array}{l}\text { Rapid floc formation and faster settling } \\
\text { than alum. }\end{array}$ & $\begin{array}{c}\text { Unusually utilized, little } \\
\text { full-scale data compared to } \\
\text { other aluminium } \\
\text { derivatives }\end{array}$ \\
\hline 4 & $\begin{array}{l}\text { Ferric Sulphate } \\
\quad \mathrm{Fe}_{2}\left(\mathrm{SO}_{4}\right)_{3}\end{array}$ & Effective when $\mathrm{pH} 4-6$ and $8.8-9.2$ & $\begin{array}{l}\text { Generally, need to add } \\
\text { alkalinity }\end{array}$ \\
\hline 5 & $\begin{array}{l}\text { Ferric Chloride } \\
\mathrm{FeCl}_{3} \cdot 6 \mathrm{H}_{2} \mathrm{O}\end{array}$ & Effective when $\mathrm{pH} 4-11$ & $\begin{array}{l}\text { Consumes more alkalinity } \\
\text { as alum }\end{array}$ \\
\hline 6 & $\begin{array}{l}\text { Ferrous Sufate } \\
\text { (Copperas) } \\
\mathrm{FeSO}_{4} .7 \mathrm{H}_{2} \mathrm{O} \\
\end{array}$ & Moderate effect of $\mathrm{pH}$ & $\begin{array}{l}\text { Percentage of dissolved } \\
\text { solids salts enhanced in } \\
\text { water. }\end{array}$ \\
\hline 7 & Lime $\mathrm{Ca}(\mathrm{OH})_{2}$ & $\begin{array}{l}\text { Commonly utilized, effective, may not } \\
\text { add dissolved solids salts to effluent. }\end{array}$ & $\begin{array}{l}\text { Depend on } \mathrm{pH} \text {, produces } \\
\text { huge amounts of sludge, } \\
\text { excess dose is not effective. }\end{array}$ \\
\hline
\end{tabular}

Oleifera is a cost-effective, environment-friendly, simple, flexible, reliable water to treat low and high turbid water $[10,11]$. Aluminum sulphate is extensively utilized globally as a common coagulant, however, the application of aluminum sulphate as coagulant leads to Alzheimer's disease which is integrated with aluminum in the water intended for human consumption. By the application of aluminum as a coagulant generates sludge on a large scale and it required supplementary treatment to dispose of the sludge $[12,13]$. Figure 1, shows the Efficiency (\%) of Moringa oleifera and Aluminum Sulphate. Water treatment cost will be increased to adjust the $\mathrm{pH}$ of the water. This can be achieved by using high concentration of alum dose. [14,15]. The shelled M. oleifera seeds reveal an ample potential for being exploited as an inexpensively feasible and native pre-treatment approach in the present technology of wastewater treatment $[14,16]$. In order to sort out issues related to chemical coagulant like formation of fog, adverse reaction etc, numerous studies were made. It is found that the natural coagulants are more beneficial, effective. These natural coagulants are extracted from microorganisms, animals or plants [17]. $M$. oleifera pods are indigenous, economical and are easily available in huge quantities as raw material that can be used for various industrial appliances to lower the cost of effluent treatment [18]. The seeds of a variety of species restrain cationic polyelectrolytes which proved to be efficient in the treatment of water, as a substitute for aluminum sulphate [19]. Parts of M. oleifera tree is rich in nutrients (protein, vitamins and minerals) and has numerous applications in medical sector. So, the tree is known as miracle tree [20]. The application of chemical coagulants exhibited the main disadvantages of $\mathrm{pH}$ adjustment and high operating cost [21]. M. oleifera is eco-friendly, biodegradable, non-corrosive, and there is no toxic effect once the dose of coagulant is used for wastewater treatment [22-26].

The objective of the study was to minimize different parameters of wastewater quality such as turbidity, colour, COD using the varied doses of $M$. oleifera. 


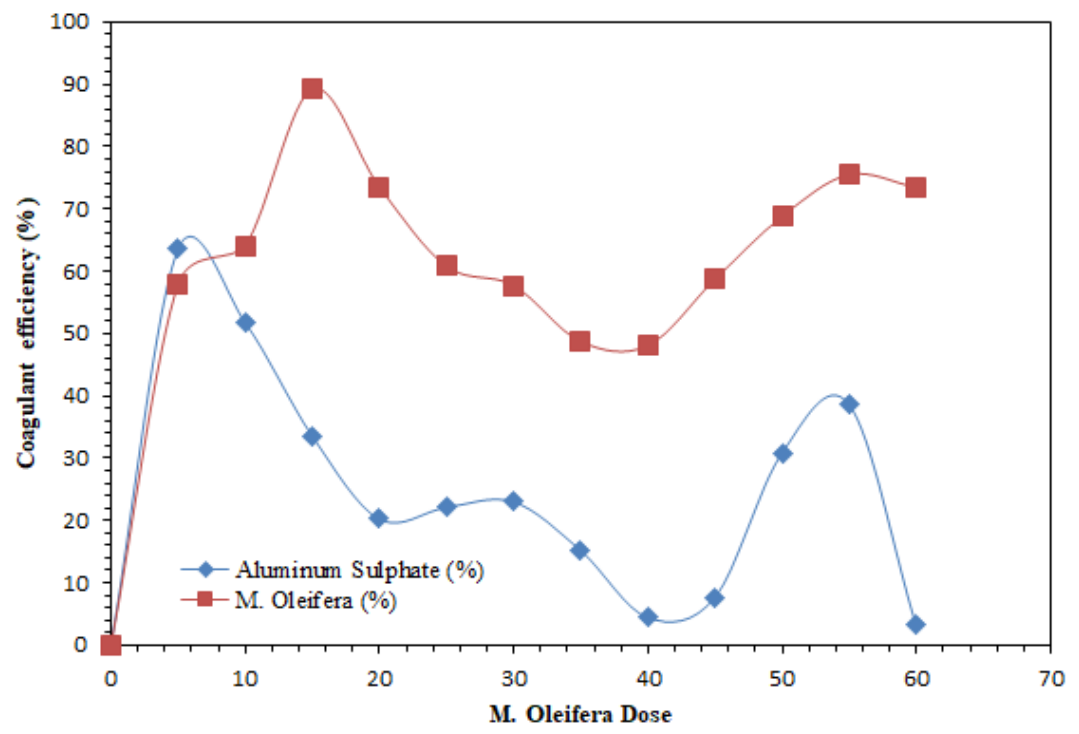

Figure 1 Efficiency (\%) of M. oleifera and aluminum sulphate.

\section{Material and methods}

M. oleifera seeds were collected locally from Ahmednagar, Maharashtra, India. Best quality dry brown seeds were selected and the seed was crushed to a fine powder using a regular electric blender. Powder is then sieved using $250 \mu \mathrm{m}$ sieve and weighted using an analytical balance. There are 3 main processes involved in preparation of M. oleifera seed coagulants are flour (seed powder), extraction of protein and purification [30,35]. Steps involved in preparation of seed powder enhances the performance rate [30]. Figures 2 and $\mathbf{3}$ shows the main process involved in the preparation of seed powder. For extraction of coagulant of about $2 \mathrm{gm} \mathrm{M}$. oleifera seeds powder was added to various salts $\mathrm{NaCl}, \mathrm{KCl}$, $\mathrm{NaNO}_{3}$, and $\mathrm{KNO}_{3}$ in several concentrations. Magnetic stirrer (REMI (Model, 2MLB)) was used to mix the mixture for $0.5 \mathrm{~h}$ at room temperature. The supernatant was filtered by using Whatman paper 42 , and the residual was dried at room temperature for $24 \mathrm{~h}[21,27]$.

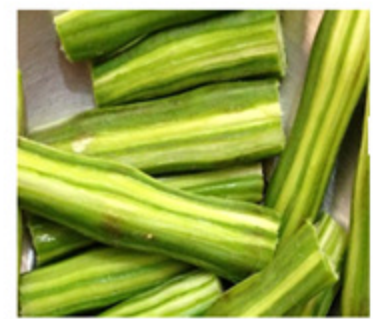

M. oleifera

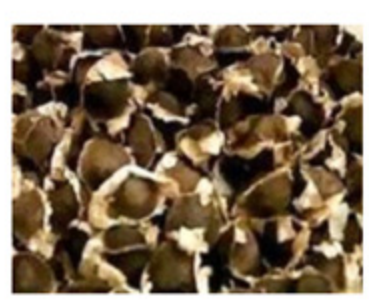

$M$. oleifera seed kernel

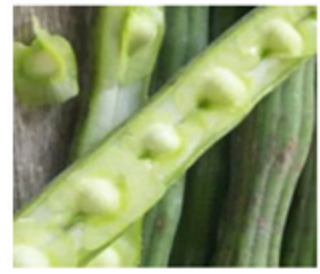

M. Oleifer $a$ peel

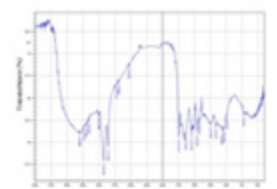

IR spectra of $M$. oleifera

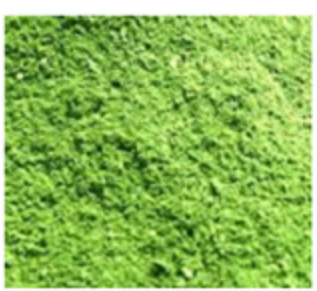

M. oleifera powder

Figure 2 Main process involved in M. oleifera seeds processing. 


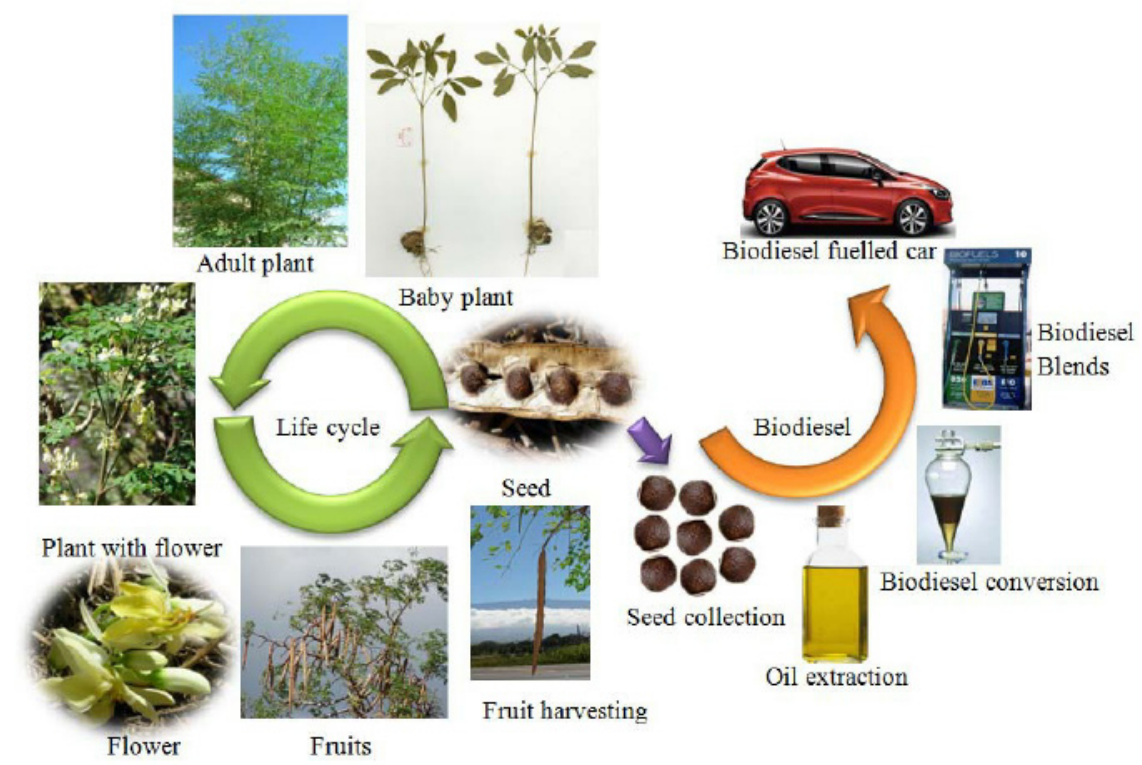

Figure 3 Moringa oliefera life cycle and extraction of oil from seed [36].

\section{Preparation of synthetic wastewater}

Synthetic wastewater was prepared by adding 0.1 to $2 \mathrm{gm}$ of milk powder/L of tap water [28]. For complete dispersion, the suspension was stirred for $10 \mathrm{~min}$. To monitor the coagulation activity of $M$. oleifera seed, the Jar test was performed and turbidity removal efficacy was measured. $\mathrm{NaOH}$ and $0.1 \mathrm{~N}$ HCL solutions were used to regulate the $\mathrm{pH}$ of the solution for jar test.

\section{Bio-sorbent characterization}

Characteristics of $M$. oleifera seeds were investigated by using the infrared spectra analysis at New Arts Science, Commerce College Ahmednagar, Maharashtra, India, in the range 4,000-500 per cm. O-H stretching at frequency 3,420 per $\mathrm{cm}$ comprising of fatty acids, protein, carbohydrates, and the lignin components. The peak frequency of 2923 and 2852 per $\mathrm{cm}$ represents $\mathrm{C}-\mathrm{H}-\mathrm{CH}_{2}$ group. Stretching frequency $1,750-1,640$ per $\mathrm{cm}$ represents the carbonyl group $(\mathrm{C}=\mathrm{O})$, fatty acids, lipid, protein and amides [29]. Figure 4 illustrates the M. oleifera seeds infrared spectrum. Analysis of M. oleifera seeds contain protein $36.90 \%$, Fat $37.25 \%$, carbohydrates $16.38 \%$, Crude fibre $12.85 \%$, moisture $6.41 \%$ and ash $3.06 \%$ [34]. Table 4 shows the characteristics of M. oleifera seeds after extraction [30].

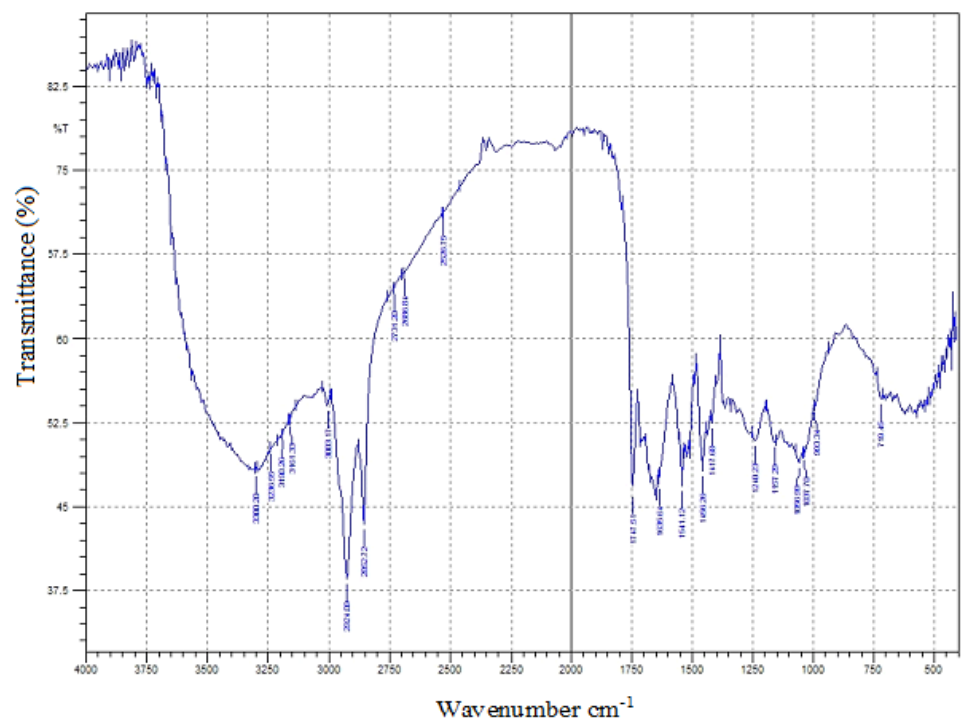

Figure 4 FTIR spectra of $M$. oleifera seeds powder. 
Table 4 Characteristics of $M$. Oleifera seeds after extraction [30].

\begin{tabular}{|c|c|c|c|c|c|}
\hline Sr. No & Parameters & value & Units & Fatty acids & Value (\%) \\
\hline 1 & $\begin{array}{c}\text { Dry residue } \\
\text { (without } \mathrm{NaCl} \text { ) }\end{array}$ & 3.29 & $\mathrm{~g} / \mathrm{L}$ & Lauric acid (C12:0) & 0.1 \\
\hline 2 & Nitrite $\left(\mathrm{NO}^{-}\right)$ & 3.96 & $\mathrm{~N} \mathrm{mg/L}$ & Myristic acid (C14:0) & 0.1 \\
\hline 3 & Ammonium $\left(\mathrm{NH}_{4}{ }^{+}\right)$ & 0.06 & $\mathrm{~N} \mathrm{mg/L}$ & Palmitic acid (C16:0) & 7.8 \\
\hline 4 & Phosphate $\left(\mathrm{PO}^{3-}\right)$ & 0.05 & $\mathrm{Pg} / \mathrm{L}$ & Palmitoleic acid (C16:1) & 2.2 \\
\hline 5 & Phosphorous $\left(\mathrm{P}_{4}\right)$ & 0.07 & $\mathrm{Pg} / \mathrm{L}$ & Stearic acid (C18:0) & 7.6 \\
\hline 6 & Isoelectric points & $10-11$ & unitless & Oleic acid (C18:1) & 67.9 \\
\hline 7 & Molecular weight & $6.5-14$ & $\mathrm{kDa}$ & Linoleic acid (C18:2) & 1.1 \\
\hline 8 & Oxidability, $\mathrm{KMnO}_{4}$ & 1.08 & $\mathrm{O}_{2} \mathrm{~g} / \mathrm{L}$ & Linolenic acid (C18:3) & 0.2 \\
\hline 9 & Protein content ${ }^{\mathrm{b}}$ & 1,832 & $\mathrm{mg} / \mathrm{L}$ & Archidic acid (C20:0) & 4.0 \\
\hline 10 & Protein content $0.01 \mathrm{M}^{\mathrm{a}}$ & 1,290 & $\mathrm{mg} / \mathrm{L}$ & Eicosenoic acid (C20:1) & 1.5 \\
\hline 11 & Protein content $0.1 \mathrm{M}^{\mathrm{a}}$ & 4,388 & $\mathrm{mg} / \mathrm{L}$ & Behenic acid (C22:0) & 6.2 \\
\hline 12 & Protein content $1 \mathrm{M}^{\mathrm{a}}$ & 4,499 & $\mathrm{mg} / \mathrm{L}$ & Lignoceric acid (C24:0) & 1.3 \\
\hline
\end{tabular}

a: $\mathrm{NaCl}$ extract, b: Water extract

\section{Coagulation test}

To reduce the turbidity of synthetic dairy wastewater the effective dose of coagulant was determined by performing Jar test. Tests were performed using $1 \mathrm{~L}$ circular jar. $60 \mathrm{~s}$ rapid mixing (125 $\mathrm{rpm}$ ) followed by $15 \mathrm{~min}$ slow mixing $(40 \mathrm{rpm})$ for flocculation and $30 \mathrm{~min}$ for settling the solution. The supernatant sample was collected and turbidity of sample was determined. The turbidity of supernatant sample was then compared with residual sample turbidity. Initial turbidity of residual sample was 87 NTU. To validate the results all the tests were performed carefully in a triplicate. The experimentations were carried out as per IS 3025 (Part 50):2001.

\section{Results and discussion}

Influence of initial pH

M. oleifera seeds consist of crude fiber, lignin, hemicellulose, and cellulose. It also contains amino functional groups $\left(\mathrm{R}-\mathrm{NH}_{3}\right)$, carboxyl group $(\mathrm{C}=\mathrm{O})$, and fiber carbonaceous. The functional group present in $M$. Oleifera seeds is dissociated during the adsorption process at various $\mathrm{pH}$. Figure 5 shows influence of $\mathrm{pH}$ in the removal of turbidity, $\mathrm{COD}$, and colour. Turbidity is removed around $95 \%$ at $\mathrm{pH} 5$, decolourization is achieved at $94 \%$ at $\mathrm{pH} 5$. COD reduction is enhanced with an increase in $\mathrm{pH}$ (from $36 \%$ at $\mathrm{pH} 5$ to $46 \%$ at $\mathrm{pH} 8$ ) as more hydrogen ions are present at lower $\mathrm{pH}$. No any significant changes were observed in colour and turbidity in $\mathrm{pH}$ range $5-8$. M. oleifera seeds curtail the adsorption efficiency above $\mathrm{pH} \mathrm{8,} \mathrm{as} \mathrm{the} \mathrm{solubility} \mathrm{of} \mathrm{the} \mathrm{proteins} \mathrm{decreases} \mathrm{present} \mathrm{in} M$. oleifera seeds. Figure 5. Also illustrate that the efficiency of turbidity, colour and COD removal depends upon the $\mathrm{pH}$. Acidic $\mathrm{pH}$ is highly influencing the rate of degradation of parameters reason may be more $\mathrm{H}^{+}$ions are present. 


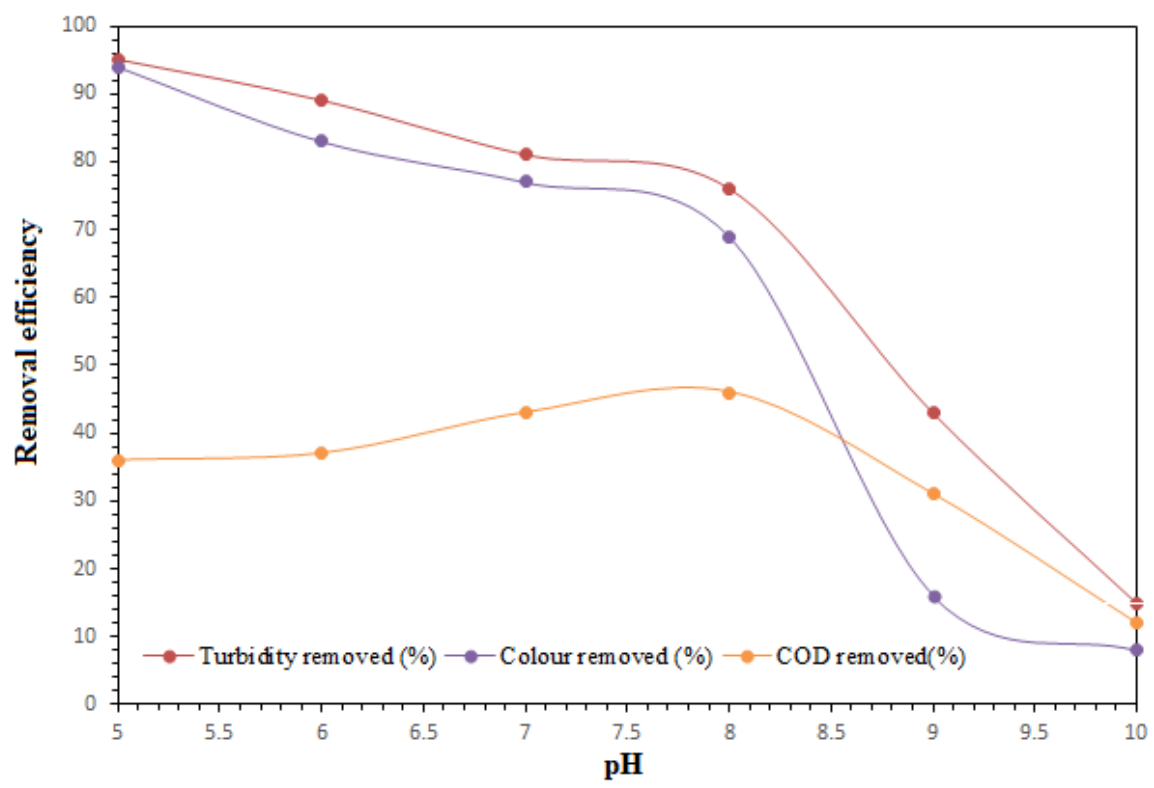

Figure 5 Influence of $\mathrm{pH}$ in removal of turbidity, colour, COD.

\section{Effect of agitation time}

Adsorption process was evaluated by using the Physico-chemical aspect. Agitation time plays a significant role in the removal of turbidity. Agitation time causes the variation in equilibrium adsorption as well as the kinetics of the adsorption process. Agitation time for experimentation was varied from 0 120 minutes. The dose of the adsorbent varied from $0.1-0.28 \mathrm{gm} / \mathrm{L}$. Figure 6 presents the efficiency of removal increases with an increase in agitation time. Reduction of turbidity and colour reached 95 and $94 \%$ respectively with agitation time of $100 \mathrm{~min}$. Beyond $100 \mathrm{~min}$ rate of degradation will be retarded reason may be desorption process will be taking place at the equilibrium time.

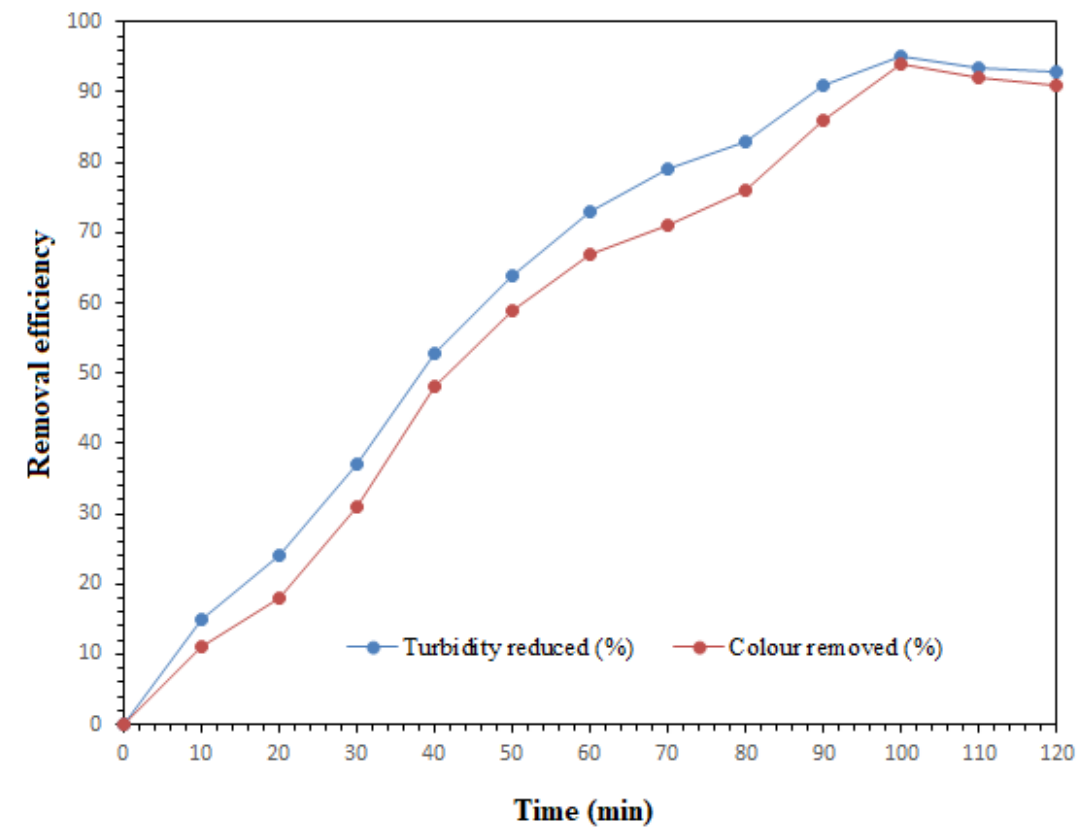

Figure 6 Effect of agitation time in removal of turbidity and colour. 


\section{Effect of MO amount}

M. oleifera has good property of coagulation-flocculation (C-F). The effect of $M$. oleifera seed amount was investigated to check the result of the adsorption process on dairy wastewater. 120-min agitation was carried out at $\mathrm{pH} 7.2$ and temperature $31^{\circ} \mathrm{C}$. Figure 7, elucidate the efficacy of turbidity and colour removal increased continuously as sorbent has potential and positively charged proteins which act as an effective coagulant. The rate of degradation of the turbidity and decolourization will directly proportional to sorbent dose up to $0.22 \mathrm{gm} / \mathrm{L}$. After achieving the optimum dose of sorbent, the rate of removal of turbidity and colour were retarded. As excess dose of sorbet stabilizes the dairy wastewater adversely.

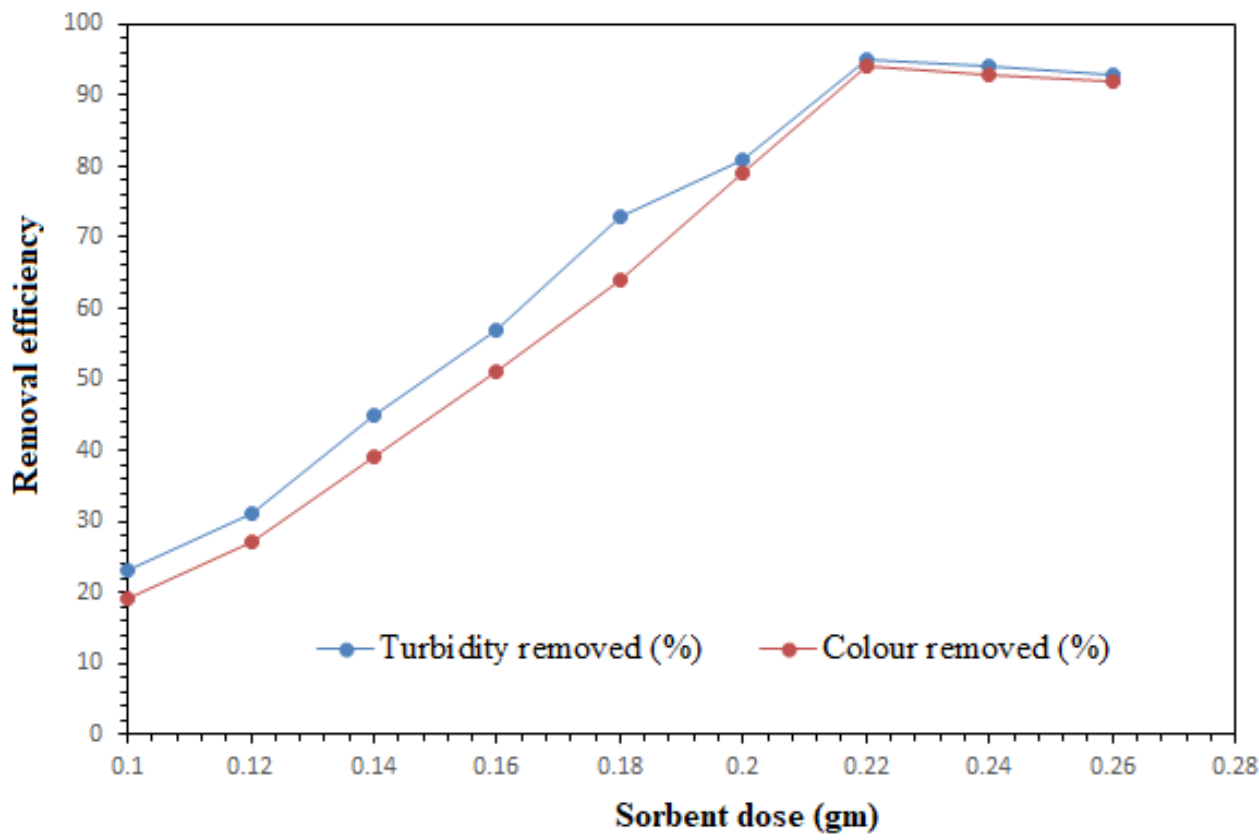

Figure 7 Effect of sorbent dose to remove the turbidity and colour.

\section{Efficacy of $M$. oleifera seeds kernel for turbidity removal}

M. oleifera seed kernel (sun-dried, oven-dried and naturally dried) were employed to find the efficacy of turbidity removal. Figure 8 shows that the effectiveness of naturally dried seed kernel is more effective than other seed kernels. A similar result was reported by author Gaikwad and Munavalli [31]. The comparison of naturally dried seed, sun-dried seeds and oven-dried seeds shows that naturally dried seeds remove turbidity upto $95 \%$, sundried seeds remove turbidity upto $52 \%$ and oven-dried seeds upto $45 \%$ at sorbent dose of $0.22 \mathrm{gm} / \mathrm{L}$.

This shows that naturally dried $M$. oleifera pod having more surface area for adsorption and interparticulate bridging which extracts the extra active ingredients [32]. The efficacy of the adsorption process depends up on various parameters such as functional group (s) contain in the sorbent, pod morphology, adsorbent contact area, polarity and pore size dispersion [33]. 


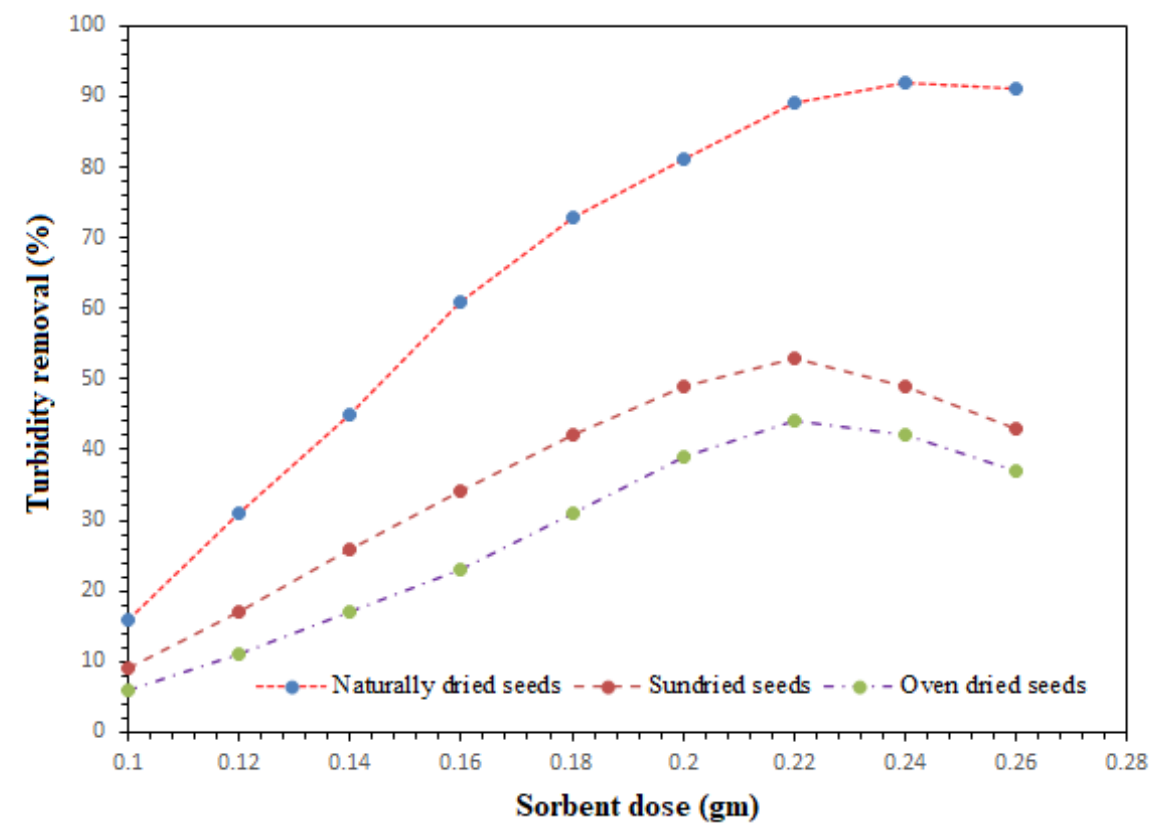

Figure 8 Efficacy of $M$. oleifera seeds kernel for turbidity removal.

\section{Conclusions}

M. oleifera seed is effectively used to eliminate turbidity and colour. M. oleifera seeds are natural, low-cost, appropriate, effective and readily available in large quantities. Fourier-transform infrared spectroscopy of $M$. oleifera seeds illustrate that it contains fatty acids, protein, carbohydrates, and the lignin components which are having more coagulation and flocculation properties. They have a robust ability to eliminate the various components of dairy wastewater as M. oleifera seed possesses superfluous coagulant property. Sorbent dose of $0.22 \mathrm{gm} / \mathrm{L}$ removes the turbidity $95 \%$, colour $94 \%$ and COD $46 \%$. Experimental results concluded that the sorption process enhances among $\mathrm{pH} 5$ to 8 . The naturally dried $M$. oleifera seeds have more efficacy than sun-dried and oven-dried seeds. The turbidity removed by naturally dried seeds is $95 \%$. Sundried seeds remove turbidity $52 \%$ and oven dried seeds $45 \%$. $M$. oleifera seeds act as a polyelectrolyte which removes the turbidity through sorption and inter-particle bridging.

\section{Acknowledgements}

The authors would like to express sincere thanks to Principal, Dr. Uday Naik, Dr. Vithalrao Vikhe Patil College of Engineering, Ahmednagar, Maharashtra, India.

\section{References}

[1] A Ndabigengesere and S Narasiah. Quality of water treated by coagulation using Moringa oleifera seeds. Wat. Res. 1998; 32, 781-91.

[2] PD Sutar, SM Bhosale and MC Chavan. Use of natural coagulants for primary treatment of dairy wastewater treatment - a review. Int. J. Trend Sci. Res. Dev. 2018; 2, 2227-30.

[3] G Vijayaraghavan, T Sivakumar and AV Kumar. Application of plant-based coagulants for waste water treatment. Int. J. Adv. Eng. Res. Stud. 2011; 1, 88-92.

[4] S Chonde and P Raut. Treatment of dairy wastewater by Moringa oleifera seeds. World J. Pharmaceut. Res. 2017; 6, 1484-93.

[5] GAP Mateus, DM Formentini-Schmitt, L Nishi, MR Fagundes-Klen, RG Gomes and R Bergamasco. Coagulation/flocculation with Moringa oleifera and membrane filtration for dairy wastewater treatment. Water Air Soil Pollut. 2017; 228, 342.

[6] HR Shamsollahi and AH Mahvi. Investigation on Moringa oleifera extracts function to reduce microbial load in water treatment. Desalination Water Treat. 2018; 133, 199-203. 
[7] Hendrawati, IR Yuliastri, Nurhasni, E Rohaeti, H Effendi and LK Darusman. The use of Moringa oleifera seed powder as coagulant to improve the quality of wastewater and ground water. IOP Conf. Ser. Earth Environ. Sci. 2016; 31, 012033.

[8] MH Mehdinejad and B Bina. Application of Moringa oleifera coagulant protein as natural coagulant aid with alum for removal of heavy metals from raw water. Desalination Water Treat. 2018; 116, 187-94.

[9] K Ravikumar and AK Sheeja. Water clarification using Moringa oleifera seed coagulant. In: Proceedings of the 2012 International Conference on Green Technologies, Trivandrum, India. 2012.

[10] CR Santana. Evaluation of the process of coagulation/flocculation of produced water using Moringa oleifera Lam. as natural coagulant. Braz. J. Petrol. Gas. 2010; 24, 111-7.

[11] R Marandi and SMB Sepehr. Removal of orange 7 dye from wastewater used by natural adsorbent of Moringa oleifera seeds. Am. J. Environ. Eng. 2011; 1, 1-9.

[12] SMA Basra, Z Iqbal, K Ur-Rehman, H Ur-Rehman and MF Ejaz. Time course changes in $\mathrm{pH}$, electrical conductivity and heavy metals $(\mathrm{Pb}, \mathrm{Cr})$ of wastewater using Moringa oleifera Lam. Seed and Alum, a comparative evaluation. J. Appl. Res. Tech. 2014; 12, 560-7.

[13] SA Muyibi and CA Okuofu. Coagulation of low turbidity surface water with Moringa oleifera seeds. Int. J. Environ. Stud. 1995; 48, 263-73.

[14] EN Ali, SA Muyibi, MZ Alam and HM Salleh. Optimization of water treatment parameters using processed Moringa oleifera as a natural coagulant for low turbidity water. In: Proceedings of the 2012 International Conference on Statistics in Science, Business and Engineering, Langkawi, Malaysia.

[15] S Katayon, MJM Noor, M Asma, LA Ghani, AM Thamer and I Azni. Effects of storage conditions of Moringa oleifera seeds on its performance in coagulation. Bioresour. Tech. 2006; 97, 1455-60.

[16] AMS Vieira, MF Vieira, GF Silva, AA Araújo, MR Fagundes-Klen, MT Veit and R Bergamasco. Use of Moringa oleifera seed as a natural adsorbent for wastewater treatment. Water Air Soil Pollut. 2010; 206, 273-81.

[17] CST Araújo, DC Carvalho, HC Rezende, ILS Almeida, LM Coelho, NMMCoelho, TL Marques and VN Alves. Bioremediation of waters contaminated with heavy metals using Moringa oleifera seeds as biosorbent. In: Y Patil (Ed.). Applied bioremediation - active and passive approaches. IntechOpen, 2013, p. 228-55.

[18] A Dalvand, E Gholibegloo, MR Ganjali, N Golchinpoor, M Khazaei, H Kamani and AH Mahvi. Comparison of Moringa stenopetala seed extract as a clean coagulant with alum and Moringa stenopetala-alum hybrid coagulant to remove direct dye from textile wastewater. Environ. Sci. Pollut. Res. 2016; 23, 16396-405.

[19] T Nkurunziza, JB Nduwayezu, EN Banadda, I Nhapi. The effect of turbidity levels and moringa oleifera concentration on the effectiveness of coagulation in water treatment. Water Sci. Tech. 2009; 59, 1551-8.

[20] BA. Nordmark, TM Przybycien, RD Tilton. Comparative coagulation performance study of Moringa oleifera cationic protein fractions with varying water hardness. J. Environ. Chem. Eng. 2016; 4, 4690-8.

[21] TC Shan, MA Matar, EA Makky and EN Ali. The use of Moringa oleifera seed as a natural coagulant for wastewater treatment and heavy metals removal. Appl. Water Sci. 2017; 7, 1369-76.

[22] A Diaz, N Rincon, A Escorihuela, N Fernandez, E Chacin and CF Forster. A preliminary evaluation of turbidity removal by natural coagulants indigenous to Venezuela. Proc. Biochem. 1999; 35, 3915.

[23] A Chandran J and D George. Use of papaya seed as a natural coagulant for water purification. Int. J. Sci. Eng. Res. 2018; 6, 43-6.

[24] R Mazaheri, MT Ghazani and A Alighardash. Effects of Moringa peregrina and Ferric Chloride $(\mathrm{FeCl} f)$ on water treatment sludge dewatering biosciences. Biotech. Res. Asia 2018; 15, 975-80.

[25] AP Trevisan, EB Lied, FL Fronza, KU Devens and SD Gomes. Cassava wastewater treatment by coagulation/flocculation using Moringa oleifera Seeds. Chem. Eng. Trans. 2019; 74, 367-72.

[26] AS Taiwo, K Adenike and O Aderonke. Efficacy of a natural coagulant protein from Moringa oleifera (Lam) seeds in treatment of Opa reservoir water, Ile-Ife, Nigeria. Heliyon 2020; 6, e03335.

[27] MR Gidde, AR Bhalerao and CN Malusare. Comparative study of different forms of Moringa oleifera extracts for turbidity removal. Int. J. Eng. Res. Dev. 2012; 2, 14-21.

[28] AMS Vieira, MF Vieira, GF Silva, AA Araujo, MR Fagundes-Klen, MT Veit and R Bergamasco. Use of Moringa oleifera seed as a natural adsorbent for wastewater treatment. Water Air Soil Pollut. 2010; 206, 273-81. 
[29] CST Araujo, EI Melo, VN Alves and NMM Coelho. Moringa oleifera Lam. seeds as a natural solid adsorbent for removal of AgI in aqueous solutions. J. Braz. Chem. Soc. 2010; 21, 1727-32.

[30] DL. Villasenor-Basulto, PD Astudillo-Sánchez, JD Real-Olvera and ER Bandala. Wastewater treatment using Moringa oleifera Lam seeds: A review. J. Water Proc. Eng. 2018; 23, 151-64.

[31] VT Gaikwad, GR Munavalli. Turbidity removal by conventional and ballasted coagulation with natural coagulants. Appl. Water Sci. 2019; 9, 130.

[32] DPT Joseane, FL Guilherme and FZ Ricardo. Coagulant and natural polymer: Perspective for treatment of water. Plast. Polym. Tech. 2013; 2, 55-62.

[33] TC Shan, MA Matar and EA Makky. The use of Moringa oleifera seed as a natural coagulant for wastewater treatment and heavy metals removal. Appl. Water Sci. 2017; 7, 1369-76.

[34] MR Gidde, AR Bhalerao and CN Malusare. Comparative study of different forms of Moringa oleifera extracts for turbidity removal. Int. J. Eng. Res. Dev. 2012; 2, 14-21.

[35] SK Kansal and A Kumari. Potential of M. oleifera for the treatment of water and wastewater. Chem. Rev. 2014; 114, 4993-5010.

[36] AK Azad, MG Rasul, MMK Khan, SC Sharma and R Islam. Prospect of Moringa seed oil as a sustainable biodiesel fuel in Australia: Review. Proc. Eng. 2015; 105, 601-6.

[37] C David, R Narlawar and M Arivazhagan. Performance evaluation of Moringa oleifera seed extract (MOSE) in conjunction with chemical coagulants for treating distillery spent wash. Indian Chem. Eng. 2016; 58, 189-200. 